\title{
"Reading guidance as a part of Guidance": A popular philosophy of reading guidance in Japan developed by Michio Namekawa in the 1940s
}

\author{
Yuriko Nakamura \\ Assistant Professor \\ Doshisha University \\ Japan
}

In this study, the author examines the development of Michio Namekawa's philosophy on reading guidance, dokusho shido, which has been since the late 1940s one of the two pillars of school library philosophy in Japan. Namekawa is recognized as one of the key persons to cultivate the practice and philosophy of reading guidance in post-war Japan. To conduct the research, the author collects and examines all of Namekawa's historical documents from the pre- to early postWWII periods, when he developed his theory of reading guidance. The author finds that Namekawa's philosophy can partially be traced back to the war period at which time a children's cultural improvement movement occurred. Then, under the occupation after the war, the CIE Education Division led Namekawa to shape his philosophy and curriculum more concretely. Around 1949, he found important components of the concept of integrating reading guidance into a students' personal life-Guidance, which Namekawa maintained throughout the post-war period.

school library philosophy, reading guidance, Michio Namekawa

\section{Introduction}

In this study, the author examines the development of Michio Namekawa's philosophy on reading guidance, dokusho shido, which has been acquired as one of the two pillars of the school library philosophy by many Japanese teachers and librarians throughout post-war Japan. To conduct the research, the author collects and examines all of Namekawa's historical documents (books and articles) from the pre- to early post- WWII periods, especially in the 1930s and 1940s when he first developed his theory of reading guidance, in order to see how he developed his theory in his writings.

This research would probably imply how deeply the need for reading guidance for children is rooted in the Japanese belief in the importance of reading throughout life. Contrary to this, it seems that many Japanese have not recognized the need for a concrete base of the reading guidance philosophy; in fact, there has not been a lot of discussion over the theoretical basis of reading guidance these years, although the word of reading guidance, dokusho shido has been mentioned on many occasions. For an example, Japanese National 
Diet passed the "Law on the Promotion of Reading Activities for Children" in 2001, and the basic plan for realizing the philosophy of the law was reported by the MEXT (Ministry of Education, Culture, Sports, Science and Technology) after that (The International Library of Children's Literature, 2004). Throughout the plan, practicing reading guidance, dokusho shido, at home, in the communities, libraries and school libraries was proposed, though it is not clearly shown what steps to take to provide reading guidance to the children, as if the related people are supposed to know what to do. There has not been a lot of discussion for the better practice of reading guidance. It seems that reading guidance has not been theoretically developed and has just been an expert librarians' implicit knowledge, whereas it has been challenged by some researchers to develop the information literacy instruction based on scientific research, especially in the fields of LIS and the other related science. However, one Japanese teacher, Michio Namekawa (1902-1992) had tried to develop a philosophy throughout his life and this research would show the core of his theory and examine its development. Reviewing Namekawa's thoughts might give us a chance to rethink the position of reading guidance in the educational practice and theory base for the school library.

\section{The previous research on Namekawa and dokusho shido}

\section{Michio Namekawa}

Michio Namekawa (1902-1992) was an elementary school teacher famous for his commitment to Japanese-language pedagogy and enrichment of children's culture, with special interests in writing (composition) instruction, reading guidance, and school libraries. The author's past research (Nakamura, 2006) shows that Namekawa was a key figure when the school library theory was reformed, with suggestions and guidance from American librarians, during the occupation of Japan just after WWII. At the time, the educational function of school libraries and their personnel was rebuilt with two pillars of "instruction in the use of books and libraries" and "reading guidance" in Gakko Toshokan no Tebiki (School Library Mannual) published in 1949, and this still seems to have influence on Japanese understanding of the roles of the school library, as MEXT has proposed, since the 1990s, that the school library has two roles of "learning information (gakushu joho) centre" and "reading (dokusho) centre".

The most of the past research done by other Japanese scholars focuses on Namekawa's work in the post-war period; however, historical documents show Namekawa had engaged in educational practices related to children's reading quite proactively from the pre-war period, and started to develop a theory of reading guidance based on his teaching and studying experience. Therefore, the author's intention in this research is to examine exactly when and how his theory developed, focusing on the pre-war and wartime periods.

\section{dokusho shido (reading guidance)}

The word dokusho shido (reading guidance) was used often during WWII by public librarians and the Ministry of Education (Okuizumi, 1994, 1992). After the war, librarians, mostly the public librarians, reflected on their past practices and thought that some of their reading guidance activities during the war played a part in indoctrinating young people with 
an ultra-nationalistic attitude through reading. Then it seems that the term dokusho shido became almost allergenic as many public librarians had regrets about their commitment to the war. There have been almost no writings by Japanese public librarians who advocate dokusho shido in the library after the war.

However, the same word seems to have been naturally accepted by teachers and school library personnel in the post-war Japan. That is, from one point of view, most likely, partly due to the leadership of Namekawa and his theory appealing to a common sense of Japanese. The school library got systematized under the new educational law established in 1947, and educational activities around school libraries prevailed after the war in Japan. Then, dokusho shido in and around the school library has also received attention of teachers and parents. Namekawa was probably the only person who had kept working on making a theoretical base for reading guidance throughout the life. Since Namekawa passed away in 1992, research on history of reading guidance as well as that on Namekawa had progressed (Kuwahara, 1993; Adachi, 1995a, 1995b, 1997, 1998, 1999; Goto, 1996; Kurosawa, 2003; Yamaguchi, 2003; Horikawa, 2005), although most of them focus on Namekawa's activities in the post-war period.

\section{Development of the reading guidance theory by Namekawa}

\section{The pre-war and wartime periods: Exploring interests in non-textbook reading materials and in the children's cultural improvement movement}

Namekawa started out as an elementary school teacher in Akita, a northern city of Honshu, and in 1932 became a teacher in Seikei Elementary School, one of the most prestigious private elementary schools in Tokyo which was established in 1915 and based on a child-centred philosophy. Since the time in Akita, he had been interested in using nontextbook reading materials in his educational practice (Namekawa, 1993). Since Taisho era (1912-1926), more teachers had started to pay attentions to books for children beside textbooks, which books were called kagai-yomimono (out-of-curricular reading materials). He recalled that senior teachers in Seikei Elementary School told him to be responsible for the school library and to collect only "good" books, no manga nor vulgar books (Namekawa, 1979). It was his first experience in taking care of the school library, and during the period, he said he had focused his activities mostly on reading promotion (Namekawa, 1979).

The Second Sino-Japanese War occurred in 1937. In the following year, 1938, the Interior Ministry started cleaning up children's books (magazines, picture books, manga and so on). In the next year, the Ministry of Education started recommending children's books, while at the same time the enrichment movement of "children's culture (jido bunka)" was occurring among teachers. Namekawa got deeply involved in the jido bunka movement and the Ministry of Education's project. Ministry of Education, as well as Namekawa, stated that children's parents and teachers should choose and provide appropriate books to conduct reading guidance. However, after a few years, in the end of FY1941 (assumingly March 1942), he was taken away from the committee of selecting books for the Ministry of Education's project, probably because he was recognized as a liberalist (Namekawa, 1997). 
In those days, Namekawa started to develop his theory on reading guidance. He pointed out two meanings/directions of reading guidance/reading training in Theory of Children's Culture (jido bunka ron) published in 1941 (Kokugoo Kyoiku Gakkai, 1991), and An Attempt at Interpretation of Literature for Small Citizens (sho kokumin bungaku shiron) published in 1942 (Namekawa, 1942). He clamed in those books that there were two meanings or directions: guiding children on what to read and on how to read. In later years, Namekawa said that before him, there had been just a few books concerning what to read mostly in relation to the selection of children's books for the library (Namekawa, 1970). It was he who initiated the development of reading guidance theory in the early 1940s. However, its historical backdrop was the children's cultural "improvement" in the wartime and that, was a kind of "cleanup" of "bad" culture by the government and the authorities, not only the project by Ministry of Interior. Therefore, it is so difficult to evaluate his work in this period and it can be easily criticized because of his part in education in the wartime. But his enthusiasm for giving children good books was probably a noble move from his experience and educational practice with children.

\section{The post-war period: Reaching to the belief "reading guidance as a part of a daily-life Guidance"}

After the war, in the spring of 1947 when the post-war new school system started, Namekawa was told to help starting a campaign for reading which fit in with conditions of Japan by American officers and consultants in CIE, GHQ/SCAP (Civil Information and Education Section, General Headquarters, Supreme Commander of the Allied Powers) (Namekawa, 1993). He wrote a curriculum for reading guidance and lectured to Japanese teachers in several occasions, under American supervision (Namekawa, 1979). Through these experiences, Namekawa's philosophy on reading guidance became more concrete and developed into a curriculum. For example, a curriculum for the elementary school published in 1949 was composed of the following 6 elements (for the first and second grades, $F$ was omitted): A. guidance on attitude toward reading; B. guidance on medical and sanitary affairs of reading; C. guidance on books; D. guidance in the library; E. guidance about the library; F. guidance in the area of reading (Namekawa, 1949a; 1949b). Namekawa said, in developing curriculum, resources from the US were helpful. He translated a part of the Chapter 7 "Lessons On the Use of the Library" of North Carolina School Library Handbook published in the North Carolina, US, in 1942 (Douglas, 1942) (Namekawa and Inagaki, 1949). Namekawa tried to combine the ideas of reading guidance and instruction in the use of books and libraries from the US but, later on, it turned out to be difficult (this would require our further research).

In this period, one of the educational philosophy of so-called "Guidance" was introduced from the U.S., mostly through the resources given by the Americans of CIE. The word was translated into several Japanese words and one of the translations was "seikatsu shido (literally meaning "life guidance")." The word means a daily life guidance to teach students how to behave and live. The life of Japanese and their children was hard just after the war and the word seikatsu shido had been developed since the pre-war period among teachers who were interested in child-centered education, which became popular just after the war ended. Namekawa had worked on a daily-life guidance from another point of view, that is in teaching writing (composition) through letting children write about their life, since the pre-war period. Namekawa applied and integrated those experience and ideas into his reading guidance philosophy. In November 1948, he first mentioned "reading guidance as a part of Guidance" as follows: "Reading guidance is not just guiding how to read which is a 
narrow meaning, but that is guiding reading in the life which is a broad meaning. That is, reading guidance does not produce any meaningful result, if it is not provided as a part of Guidance. (snip) I always said simply that "reading guidance is cultivated reading power and mind which is a part of living power" (Sekino and Namekawa, 1948). Namekawa developed his reading guidance philosophy with the central core of the belief shown at the early postwar period.

\section{Conclusion and discussion}

In this study, the author examines how Michio Namekawa's philosophy on reading guidance (dokusho shido) developed. Through examination of Namekawa's historical documents the author found that the outset of Namekawa's philosophical development, which blossomed in the post-war period, could be determined in the book, which he co-authored, Theory of Children's Culture (jido bunka ron) published in 1941 during the war. While the children's cultural improvement movement was transpiring in the late 1930s, his interest concerning children's books and reading deepened. Under the occupation after the war, the CIE Education Division led Namekawa to shape his philosophy and curriculum more concretely. Around 1949, he found important components of the concept of integrating reading guidance into a student's personal life-Guidance which Namekawa maintained throughout the post-war period.

The experience of Namekawa and the Japanese recall the following questions related to the education on reading and the reading promotion for children, which many school librarians may be interested in: "Is there a unique area of reading guidance, aside from a reading promotion and a subject of language study?" and "Can reading guidance philosophy be one of the two pillars of the school library philosophy or should it be integrated into the information literacy instruction?"

\section{Reference}

Adachi, Sachiko (1995a). "Reading guidance philosophies in the information society: the meaning of reading guidance philosophies by Namekawa Michio, Kurasawa Eikichi, Omura Hama in the Showa era of the 40s," Jinbunkagaku Kyoiku Kenkyu, No.22, p.105-113 (originally in Japanese)

Adachi, Sachiko (1995b). "A Study on Namekawa Michio's Teaching of Reading." The Science of reading, Vol.41. No.2. p.1-8 (originally in Japanese)

Adachi, Sachiko (1997). “The Influence of Seikei Educational Thought on Namekawa Michio's Teaching of Reading." The Science of reading, Vol.41, No.3, p.114-123 (originally in Japanese)

Adachi, Sachiko (1998). "History of establishing Namekawa Michio’s reading guidance philosophy." Journal of language teaching, No.25, p.153-163 (originally in Japanese)

Adachi, Sachiko (1999). "Namekawa Michio's view of children's culture and reading guidance." Journal of language teaching, No.26, p.11-23 (originally in Japanese)

Douglas, Mary P. (1942). North Carolina School Library Handbook. Raleigh, NC: State Superintendent of Public Instruction (Third Edition)

Goto, Yo (1996). "Trend of "reading guidance" and the school library." Journal of the Senshu University Research Society, No.59, p.161-182 (originally in Japanese) 
Horikawa, Teruyo (2005). "A style of reading guidance using the reading center." For the development of school library media center's theory, Research Committee, Japan Society of Library and Information Science ed., Tokyo: Bensey Publishing, p.115-134 (originally in Japanese)

International Library of Children's Literature (2004). The Promotion of Reading Activities for Children in Japan. Tokyo: the library, http://www.kodomo.go.jp/english/kn/bnum/2004-kn001.html (last accessed on 5 May 2008)

Kokugo Kyoiku Gakkai (1941). Theory of Children's Culture. Tokyo: Iwanami Shoten (originally in Japanese)

Kurosawa, Hiroshi (2003). "History and foresight of reading guidance." Toshokan Johogaku Kenkyu, No.3, p.127 (originally in Japanese)

Kuwahara (1993) "A memorial address: Following the track of dokusho shido." Gekkan Kokugo Kyoiku Kenkyu, No.254, p.58-61 (originally in Japanese)

Nakamura, Yuriko (2006). How do we integrate guidance on reading and instruction on information use? Seventy-second IFLA General Conference and Council. Seoul: Korea, http://www.ifla.org/IV/ifla72/papers/142-Nakamura-en.pdf (last accessed on 6 May 2008)

Namekawa, Michio (1942). An Attempt at Interpretation of Literature for Small Citizens. Tokyo: Teikoku Kyoiku Shuppanbu (originally in Japanese)

Namekawa, Michio (1949a). Reading Guidance for Children, Tokyo: Kokudosha

Namekawa, Michio (1949b). My reading guidance. Dokusho Sodan, Vol.1, No.2, 1949.7.25, p.6-7

Namekawa, Michio and Inagaki, Tomomi (1949). Activities in Seikatsu Gakko. Tokyo: Maki Shoten (originally in Japanese)

Namekawa, Michio (1970). Comprehensive reading guidance. Tokyo: Tokyodo Shuppan. (originally in Japanese)

Namekawa, Michio (1979). "The dokusho shido and school library management in Seikei Elementary School," Gakko Toshokan. No.341, p.47-49, 51-52

Namekawa, Michio (1993). Experiential history of children's culture. Tokyo: Kokudosha (Namekawa interviewed by Hiroyuki Tomita, originally in Japanese)

Okuizuim, Kazuhisa (1994). The evolution of dokusho shido in the war time period, Library World, Vol.46, No.1, p.2-22 (originally in Japanese)

Okuizumi, Kazuhisa (1992). The introduction of dokusho shido in libraries in the pre-war period: 1935-1940, Library World, Vol.44, No.1, p.2-16 (originally in Japanese)

Sekino, Yoshio and Namekawa, Michio (1948). “Conversation: about reading guidance.” Seikatsu Gakko, Vol.3, No.9, p.1-12

Yamaguchi, Shinya (2003). "A Study on Reading Guidance as A Part of Guidance in School Library Documents (1945-1954)." Journal of Japanese language and Japanese literature, Okinawa International University, Vol.7, No.2, p.1-28 (originally in Japanese)

\section{Statement of Originality}

The paper above is based upon Yuriko Nakamura's original research and the paper was conceived and written by herself and has not been published elsewhere. All information and ideas from others is referenced. 